\title{
A Prehistoric, Noncultural Vertebrate Assemblage from Tutuila, American Samoa ${ }^{1}$
}

\author{
David W. Steadman ${ }^{2,3}$ and Gregory K. Pregill 4
}

\begin{abstract}
Ana Pe'ape'a is a small cave on the southern shore of Tutuila, American Samoa. Excavations at Ana Pe'ape'a yielded 13,600+ bones of small vertebrates, dominated $(>95 \%)$ by the nonnative Pacific Rat, Rattus exulans. Represented in the owl-derived bone deposit are two species that no longer occur on Tutuila, the Pacific Boa (Candoia bibroni) and the Sooty Crake (Porzana tabuensis). Based on bone counts, C. bibroni was the second most common species at the site. The third most common, the Sheath-tailed Bat (Emballonura semicaudata), is extremely rare on Tutuila today. Compared with bone records in nearby Tonga, we believe that the deposit at Ana Pe'ape'a, with a radiocarbon date of A.D. 445 to 640 , is at least $1,000 \mathrm{yr}$ too young to be dominated by extinct species.
\end{abstract}

The West Polynesian faunal region comprises Fiji, Tonga, Samoa, and the outlying islands of Rotuma, 'Uvea, Futuna, 'Alofi, and Niue (Steadman 1993a, Steadman et al. 2000). Raised limestone islands in Fiji, Tonga, and Niue have yielded rich deposits of prehistoric bones in caves and rockshelters that represent many extinct species or populations of lizards, birds, and bats (Pregill 1993, Koopman and Steadman 1995, Pregill and Worthy 2003, Steadman in press). By contrast, information on prehistoric vertebrates is very sparse in nearby Samoa (Figure 1), which lacks limestone and instead consists mainly of young basalt-rich volcanic rocks with radiometric $\left({ }^{40} \mathrm{~K}-{ }^{40} \mathrm{Ar}\right)$ ages no older than ca. $2.8 \pm 0.20$ million yr (from Upolu [Simkin et al. 1981, Keating 1985, Natland

${ }^{1}$ Financial support came from the National Science Foundation (grant EAR-9714819 to D.W.S.). Manuscript accepted 26 January 2004.

${ }^{2}$ Florida Museum of Natural History, University of Florida, Gainesville, Florida 32611.

${ }^{3}$ Corresponding author (phone: 352-392-1721 x261; fax: 352-846-0287; e-mail: steadman@flmnh.ufl.edu).

${ }^{4}$ Department of Biology, University of San Diego, San Diego, California 92110.

Pacific Science (2004), vol. 58, no. 4:615-624 (C) 2004 by University of Hawai i Press All rights reserved and Turner 1985]). Independent (formerly Western) Samoa comprises the very large islands of Upolu and Savai $i$ and their small offshore islands. American Samoa comprises Tutuila, its offshore island of Aunu'u, the Manu'a group (Ta'u, Ofu, Olosega), and the outlying atolls of Swains and Rose.

The wet volcanic soils of Samoa are well suited for sustaining forests (Whistler 1980, 1992, Elmqvist et al. 1994) but are not favorable for bone preservation. Lava tubes have produced extensive prehistoric bone records in the Hawaiian Islands (James et al. 1987, James and Olson 1991, Olson and James 1991) and the Galápagos Islands (Steadman 1986, Steadman and DeLeon 1999), but Samoan lava tubes are poorly suited for bone deposition and preservation because of flowing water, wet soils, and stagnant air saturated with humidity (Thomson 1921, Kear and Wood 1959, Hoch and Asche 1988). Archaeological excavations even at the relatively dry entrances of the Falemauga Caves on Upolu are not known to have yielded bones (Freeman 1944).

Thus, on 21 April 1999, it was a nice surprise to discover a small but dry accumulation of bone-rich sediment in a cave on Tutuila. At $141.97 \mathrm{~km}^{2}$, Tutuila is the largest island in American Samoa but still about an order of magnitude smaller than Upolu or Savai'i. Here we describe the results of this discovery, which represents Tutuila's only evidence of 


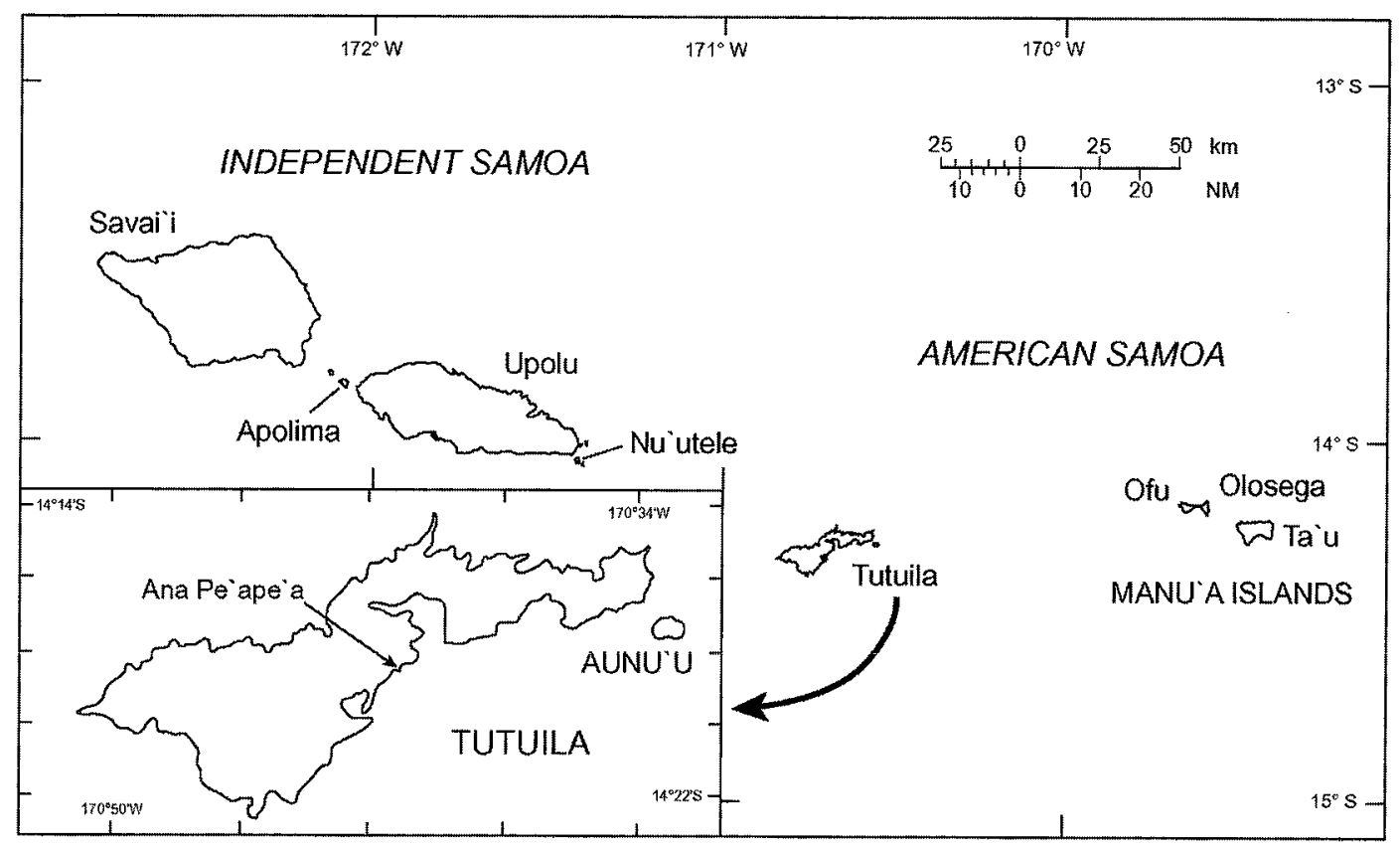

Figure 1. The location of Ana Pe'ape'a, Tutuila, American Samoa, in a regional and local context.

prehistoric vertebrates. Our findings also generate a limited discussion of the historic biogeography of Samoan reptiles and birds.

\section{MATERIALS AND METHODS}

Ana Péape'a $\left(14^{\circ} 18^{\prime} 24^{\prime \prime} \mathrm{S}, 170^{\circ} 41^{\prime} 00^{\prime \prime} \mathrm{W}\right)$ is a small (ca. $24 \mathrm{~m}^{2}$ of horizontal passage), seaward-facing cave of erosional origin at Ana Pe'ape'a Point (alternative name Mata'ae Point) on the south-central coast of rugged Tutuila (Figure 1). It lies $200 \mathrm{~m} \mathrm{SSW}$ of Matu'u Village and is visible from the coastal highway (Figure 2). Only ca. $25 \mathrm{~m}$ inland from and ca. $10 \mathrm{~m}$ above the sea, Ana Pe'ape'a presumably formed through wave action at a time when the basalt escarpment was lower relative to sea level.

The bones in Ana Pe'ape'a are mostly from Excavation Units 1 and $2(166 \mathrm{~cm}$ long by $30-80 \mathrm{~cm}$ wide by $18-40 \mathrm{~cm}$ deep), in a small deposit of dry sediment on a ledge along the cave's northern wall. Excavation Unit 3 (100 by 100 by $33-56 \mathrm{~cm}$ deep) was on the main, central floor of the cave. Excavation
Unit 4 (100 by 100 by $8-10 \mathrm{~cm}$ deep) was on a ledge on the cave's northeastern wall. Each Excavation Unit reached the basaltic bedrock of the cave. All excavation was by trowel. Levels are arbitrary vertical designations, whereas Layers reflect natural stratigraphic changes. During the excavations, on 22-23 April 1999, all sediment was dry-sieved in the field with screens of 12.5-, 6.4-, 3.2-, and 1.6$\mathrm{mm}$ mesh, thereby assuring recovery of the smallest identifiable specimens.

The bones are mostly dark reddish brown but vary in color from yellow to orange to black. In the field they were stored dry, sealed in plastic bags (Whirl-pac, Nasco), and then shipped to the Florida Museum of Natural History (UF) to be cleaned, identified, and curated. Identification of the bones was based on comparisons with modern skeletons in UF and the National Museum of Natural History, Smithsonian Institution (USNM), supplemented for reptiles by specimens from the San Diego Natural History Museum (sDNHM). Although D.W.S. sorted all of the non-Rattus bones from Ana Pe'ape'a, he did 


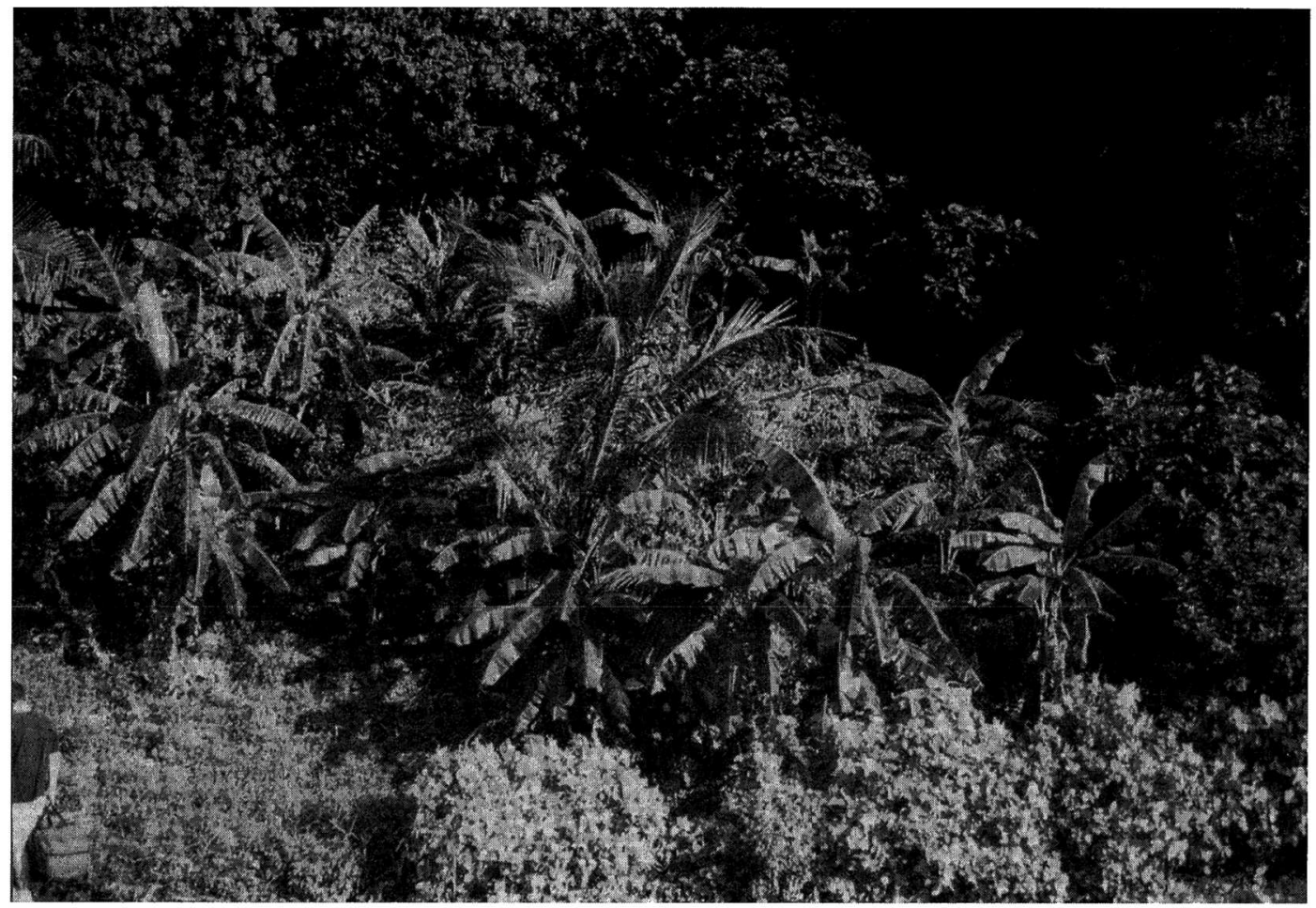

Figure 2. The entrance (upper right) of Ana Pe‘ape‘a, Tutuila, 22 April 1999. Jeffrey Sailer is walking in the left foreground.

not pick out every bone of Rattus exulans from the concentrated sediment matrix. Thus the numbers of bones in Table 1 are accurate for every species except $R$. exulans, for which at least several thousand additional bones were recovered but not counted.

\section{RESULTS}

\section{Stratigraphy and Cbronology}

The sediment at Ana Pe'ape'a consists of poorly stratified, pebbly, cobbly silt. In Excavation Units 1 and 2, it is loose, light reddish brown to dark brown, whereas in Excavation Unit 3 it is compacted and grayish brown in Layer I, becoming less indurated and variably more reddish in Layer II. The sediment in Excavation Unit 4 is light to dark yellowish brown. We found no artifacts or other cultural evidence, with the possible exception of some wood charcoal and a single fragmentary premolar of a pig (Sus scrofa) in the top of Layer II in Unit 3, and a calcaneum of a dog (Canis familiaris) in Unit 4.

Based on the radiocarbon $\left({ }^{14} \mathrm{C}\right)$ chronology of human arrival in the Fiji-TongaSamoa region (Kirch and Hunt 1993, Anderson and Clark 1999, Burley et al. 1999, Steadman et al. 2002), the presence of bones of the nonnative Rattus exulans throughout the deposit at Ana Pe'ape'a should indicate an age of less than $2,900-2,800 \mathrm{cal}$ B.P. An accelerator-mass spectrometer (AMS) ${ }^{14} \mathrm{C}$ date (Beta-134572 [Figure 3]) is 1,505 to 1,310 cal B.P. (cal A.D. 445 to 640 ), based on purified collagen (acid-alkali pretreatment, followed by ultrafiltration) from the femur of a juvenile chicken (Gallus gallus). This age is reasonable in light of the 19 taxa of vertebrates identified at Ana Pe'ape'a, which include at least four that are introduced 


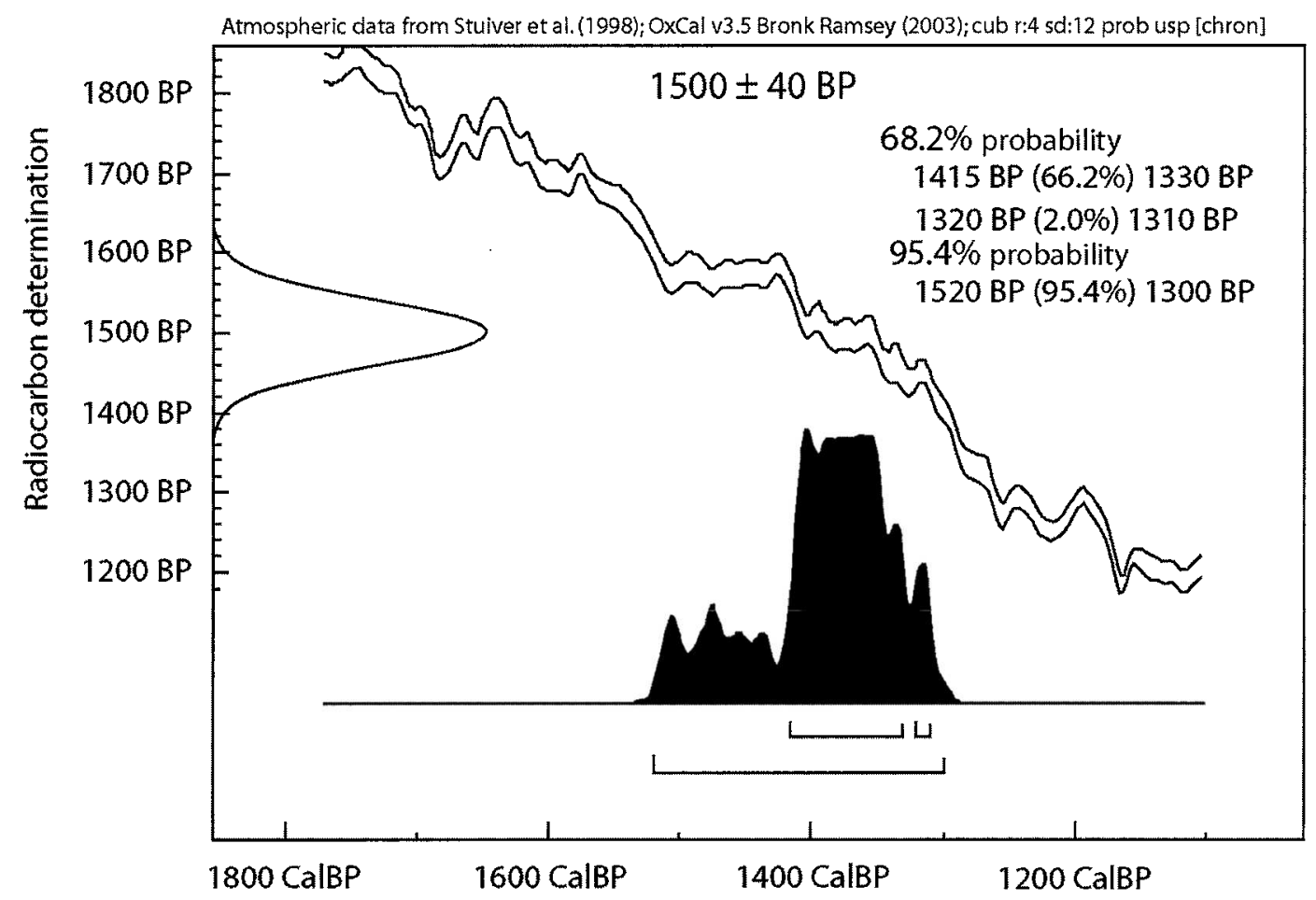

Calibrated date

Figure 3. Calibration curve for the radiocarbon date (Beta-134572) from purified collagen of a chicken (Gallus gallus) femur from Ana Pe‘ape'a, Tutuila.

(chicken, rat, dog, and pig), none that is extinct, and only two with populations that are extirpated on Tutuila (a snake and bird; see next section).

\section{Vertebrate Fauna}

All lizard taxa identified from Ana Pe'ape'a probably occur today on Tutuila. The gekko Gebyra oceanica is common in American Samoa and has been recorded from all islands. The Nactus pelagicus species group is a widely distributed complex of bisexual and unisexual species of gekkos (Zug and Moon 1995, Zug 1998). In most of Oceania $N$. pelagicus is restricted to parthenogenetic populations like those in American Samoa, where it is recorded from Tutuila and $\mathrm{Ta}^{4} \mathrm{u}$ (Schwaner 1980, Amerson et al. 1982b).
Of the three bones referred to Emoia spp., the largest (a maxilla) came from a mediumlarge skink with an estimated snout-vent length (SVL) of $110 \mathrm{~mm}$. Three species of Emoia in that size range now inhabit American Samoa: Emoia lawesii, E. nigra, and E. samoensis (Brown 1991). The last two occur today on Tutuila. Our skeletal material of these three skinks is limited to $E$. nigra, which corresponds in general morphology with the fossil maxilla. An incomplete fossil dentary differs from that of $E$. nigra in details of dentition; it came from an individual ca. $95 \mathrm{~mm}$ SVL and probably represents one of the other two species. Emoia samoensis is common on Tutuila (Schwaner 1980), whereas E. lawseii is a cryptic, terrestrial species confined to coastal strands of coral rubble. Because it occurs on Olosega, Ta'u, and tiny Aunu'u 
(Schwaner and Brown 1984), the absence of E. lawesii from Tutuila is peculiar if it is not a result of local extinction.

The Pacific Boa, Candoia bibroni, is known in American Samoa from about eight specimens, all from Ta'u (Amerson et al. 1980). This snake also is known from Savai'i and Upolu, a disjunction of about $210 \mathrm{~km}$ from Ta'u. The fossils from Tutuila represent an extinct population that helps to explain this otherwise illogical geographic hiatus. The Pacific Boa probably occurred throughout Samoa before people arrived.

The nine species of birds represent one introduced species (Gallus gallus), one seabird (Procelsterna cerulea), and seven indigenous land birds. These land birds vary in habitat preference from forest edge and successional habitats to mature forest, without any clear trend. The only species of bird no longer found on Tutuila is the small, volant rail Porzana tabuensis. On other Polynesian islands where it no longer occurs, $P$. tabuensis often survived into late prehistoric or historic times rather than being lost in Lapita times (Steadman 1993a, in press). The only native mammal we found is the sheath-tailed bat Emballonura semicaudata, which is very rare on Tutuila today (Grant et al. 1994) but probably roosted prehistorically in Ana Pe'ape'a.

We believe that the barn-owl Tyto alba was responsible for the primary bone deposit (Excavation Units 1 and 2) because: (1) it is the most commonly represented bird, including six bones of nestlings (two thoracic vertebrae, tibiotarsus, tarsometatarsus, two pedal phalanges); (2) all other bones recovered are of reptiles, birds, and mammals small enough to be eaten by $T$. alba (each of the four bones of the largest bird, the chicken, Gallus gallus, are from juveniles); (3) $95+\%$ of the bones are of Rattus exulans (Table 1), the preferred prey of $T$. alba in Oceania when available (D.W.S., pers. obs.); and (4) no cultural evidence (artifacts, charcoal, features, etc.) was found in the bone deposit. The few fish bones found in Units 3 and 4 are very small and could represent food of the piscivorous tern Procelsterna cerulea, which in turn was consumed by the barn-owls. Three of the 19 bones of $P$. cerulea (a humerus, tibiotarsus, and tarsometatarsus) are from juveniles, suggesting that this species nested near the cave. The single bones of $\mathrm{dog}$ and pig at Ana Pe'ape'a certainly are not from predation by Tyto alba but may represent animals whose carcasses, whole or in part, were taken to the cave by people, dogs, or pigs.

\section{DISCUSSION}

\section{Vertebrate Prebistory in Samoa}

Roger Green and Janet Davidson conducted field surveys and excavations on the two largest and highest Samoan islands, Upolu and Savai i, from 1957 to 1967 (Green and Davidson 1969, 1974). Their excavations yielded few bones overall (mostly fish, dog, pig, or human), and they reported no reptile or bird bones that could be identified to species (Green and Davidson 1969:241). In the Auckland Museum in 1988, D.W.S. identified 12 bones from their Lotofaga site on Upolu as follows: nine from the chicken, Gallus gallus, two of the rail Gallirallus pbilippensis, and one of the tern Anous stolidus. Each species still exists on Upolu. Subsequent excavations on Upolu in 1974 yielded no bird bones (Jennings et al. 1976).

During 15 days exploring of lava tubes on Upolu in April 1999, the only bird bones that D.W.S. found were a few surface remains of the swiftlet Collocalia spodiopygia, which still nests in the same caves. Thus we know nothing at all about prehistoric birds (or reptiles) on two of the largest, highest, most culturally important, and species-rich islands in Polynesia. This is one of the most glaring and challenging voids in the historic biogeography of Polynesian vertebrates.

The situation is slightly better in American Samoa, where only one site other than Ana Pe'ape'a has produced bones of indigenous vertebrates. The To'aga archaeological site on Ofu, a small island $\left(6.56 \mathrm{~km}^{2}\right)$ in the Manu'a Group, dates from ca. 2,800 to 1,900 yr B.P. (see various chapters in Kirch and Hunt 1993). No species of lizards or bats were recorded among the bones from To'aga (Nagaoka 1993); fishes and birds were the only indigenous vertebrates. The 74 bird bones identified from the To'aga site (Stead- 
TABLE 1

The Bone Assemblage from Ana Pe‘ape‘a, Tutuila, Expressed in Numbers of Identified Specimens (NISP)

\begin{tabular}{|c|c|c|c|c|c|c|c|}
\hline \multirow[b]{2}{*}{ Taxon } & \multicolumn{4}{|c|}{ Units 1,2} & \multicolumn{2}{|c|}{ Unit 3} & \multirow{2}{*}{$\frac{\text { Unit } 4}{\text { Layer I }}$} \\
\hline & Level 1 & Level 2 & Total & $\%$ NISP & Layer I & Layer II & \\
\hline \multicolumn{8}{|l|}{ Fish } \\
\hline Osteichthyes sp. & - & - & - & - & 5 & 4 & - \\
\hline \multicolumn{8}{|l|}{ Reptiles } \\
\hline Gebyra oceanica & 25 & 9 & 34 & $<0.25$ & 2 & - & - \\
\hline Nactus pelagicus & 1 & 4 & 5 & $<0.04$ & - & - & - \\
\hline Emoia spp. & 3 & - & 3 & $<0.02$ & - & - & - \\
\hline Lizard sp. & 9 & 2 & 11 & $<0.08$ & 2 & 1 & - \\
\hline Candoia bibroni & 317 & 157 & 474 & $<3.47$ & - & - & - \\
\hline \multicolumn{8}{|l|}{ Birds } \\
\hline Gallus gallus ${ }^{a}$ & 2 & 2 & 4 & $<0.03$ & - & - & - \\
\hline Procelsterna cerulea & 11 & 8 & 19 & $<0.14$ & - & - & - \\
\hline Porzana tabuensis & 10 & 5 & 15 & $<0.11$ & - & - & 一 \\
\hline Gallirallus pbilippensis & 1 & - & 1 & $<0.01$ & - & - & - \\
\hline Tyto alba & 14 & 10 & 24 & $<0.18$ & - & - & - \\
\hline Halcyon cbloris & 2 & 1 & 3 & $<0.02$ & - & - & - \\
\hline Foulebaio carunculata & - & 1 & 1 & $<0.01$ & - & - & - \\
\hline Aplonis tabuensis & 1 & - & 1 & $<0.01$ & - & - & - \\
\hline Aplonis atrifusca & 1 & 4 & 5 & $<0.04$ & $\ldots$ & - & - \\
\hline Bird sp. & 26 & 15 & 41 & $<0.30$ & - & - & - \\
\hline \multicolumn{8}{|l|}{ Mammals } \\
\hline Emballonura semicaudata & 105 & 35 & 140 & $<1.02$ & - & 1 & - \\
\hline Rattus exulans & $9,481+$ & $3,413+$ & $12,894+$ & $>94.29$ & 5 & 6 & 7 \\
\hline Canis familiaris ${ }^{a}$ & - & - & - & - & - & - & 1 \\
\hline Sus scrofa $a^{a}$ & - & - & - & - & - & 1 & - \\
\hline Total NISP & $10,009+$ & $3,666+$ & $13,675+$ & 100 & 14 & 12 & 8 \\
\hline Sediment volume (liters) & 81 & 33 & 114 & - & 74 & 218 & 30 \\
\hline Bone influx (per liter) & $124+$ & $111+$ & $120+$ & - & 0.19 & 0.06 & 0.27 \\
\hline
\end{tabular}

"Introduced species.

man 1990, 1993b) represent 10 species of seabirds, including five extirpated species of shearwaters and petrels (Procellariidae). The five species of land birds from To'aga include the easternmost record of a megapode $(\mathrm{Meg}$ apodius sp.: larger than $M$. pritcbardii, smaller than M. alimentum [Steadman 1993b, 1999]). Known from a fragmentary ulna and femur, this megapode is the only extinct species of land bird recovered from the To'aga site.

\section{Faunistics}

The herpetofauna of American Samoa was last reviewed by T. D. Schwaner as a part of vertebrate field surveys in 1975-1976 (Amerson et al. 1980, Schwaner 1980). The terrestrial herpetofauna includes the introduced toad Bufo marinus; the gekkos Gebyra (Peropus of Schwaner) mutilata, G. oceanica, Hemidactylus frenatus, Lepidodactylus lugubris, and Nactus (Cyrtodactylus of Schwaner 1980) pelagicus; the skinks Cryptobelpbarus poecilopleurus (Ablepharus boutonii of Schwaner 1980), Emoia adspersa (Swains Atoll only), E. cyanura (possibly including its cryptic sibling $E$. impar [see Ineich and Zug 1991]), E. lawesii, E. nigra, E. samoensis (samoense of Schwaner), and Lipinia noctua; and one snake, the Pacific Boa, Candoia bibroni.

Each of the five species of gekkos is widely distributed in Oceania. The widespread skinks are Cryptobelpharis poecilopleurus, Emoia cyanura, and Lipinia noctua. The other four species of Emoia have circumscribed distributions in Polynesia, with E. samoensis being endemic to American and Independent Samoa. Considering as well the fossil data 
from nearby Tonga (Pregill 1993), it is likely that these six species of terrestrial reptiles are indigenous to American Samoa: Emoia adspersa, E. cyanura, E. lawesii, E. nigra, E. samoensis, and Candoia bibroni. Lipinia noctua probably is a prehistoric introduction (Austin 1999), whereas Gebyra mutilata probably arrived through human agency in historic times (Fisher 1999). Hemidactylus frenatus has been on central Pacific islands no more than $50 \mathrm{yr}$ (Moritz et al. 1993). Some of the remaining species of lizards may have dispersed naturally, such as G. oceanica (Zug 1991, Fisher 1999), but the evidence is inconclusive. For any Pacific island group with indigenous lizards, the history of colonization for each species of lizard should be considered island by island.

More species of land birds have been recorded in historic times (the past two centuries) on Savai'i (31-32) and Upolu (28) than on Tutuila, which has 17 species, more than any other island in American Samoa (Pratt et al. 1987, Steadman in press). The distribution and relative abundance of modern land birds in American Samoa are well documented (Amerson et al. 1982a,b, Banks 1984, Engbring and Ramsey 1989, Freifeld 1999), but the species composition is obviously artificial, whether compared with that of Independent Samoa or evaluated only among islands in American Samoa. Nearly all of the land birds shared between the two Samoa's fall into four broad categories: aquatic/semiaquatic/ grassland species (ducks, rails), predators (barn-owl, swiftlet), canopy frugivores (pigeons, doves, starlings), and canopy nectarivores (lorikeets, honeyeaters). The only exception is the ground-dove Gallicolumba stairi, although this species is extirpated or extremely rare anywhere in Samoa. Missing from all of American Samoa are 13 species (in 12 genera) known from Independent Samoa (Steadman in press), consisting of two rails (Poliolimnas cinereus, Pareudiastes pacificus), two columbids (Columba vitiensis, Didunculus strigirostris), and nine passerines (mostly understory insectivores). Six of these 12 genera (Didunculus and five passerines) occur today or formerly in Tonga (Steadman 1993a, in press).
All or nearly all of the species that now inhabit Independent Samoa but not American Samoa probably used to live in both places. From Upolu, Tutuila is easily visible to the east, with only $70 \mathrm{~km}$ of ocean separating these large, high islands. That all islands in American Samoa are smaller than Savai $i$ and Upolu is unlikely to account for the differences in species richness. Instead we believe that habitat modification and predation, perhaps especially the former, may explain American Samoa's much poorer avifauna. Evidence for this comes from bird surveys on small islands off Upolu in April 1999 (Freifeld et al. 2001). The only one of these islands with extensive mature forest is $\mathrm{Nu}^{\text {'utele }}$ (Whistler 1983), which also has the richest avifauna. Apolima, with the same land area as Nu'utele, supports a much less rich land bird community because it is inhabited (one village of ca. 100 persons) and mostly deforested. Five of the six species of land birds that we found on Nu'utele but on no other offshore islands are forest dwellers. These species are more common in relatively mature forest than in more degraded habitats on Upolu and Savai'i (Bellingham and Davis 1988, Evans et al. 1992). Just as in the Vava'u Group of Tonga (Steadman and Freifeld 1998, Franklin et al. 1999), the columbids and passerines that are forest obligates can occur on very small Samoan islands $\left(\leq 1 \mathrm{~km}^{2}\right)$ as long as much of the forest is intact.

Based in part on the age of the bone deposit at Ana Pe'ape'a (described here) and the situation in Tonga (Steadman et al. 2002), it is possible that much of the hypothesized extinction of bird populations on Tutuila (and elsewhere in Samoa) took place within several centuries of human arrival. Thus, although informative, the bones recovered from Ana Pe'ape'a would have been even more so had they been deposited at least a thousand years earlier.

\section{ACKNOWLEDGMENTS}

For able field assistance during the excavations, we thank Holly Freifeld, Jeff Sailer, Epifania Suafo'a, and Sonny Taomia. Permission to conduct the fieldwork was kindly 
arranged by Epifania Suafo'a. For additional cooperation and assistance we thank David Addison, Peter Craig, Charles Cranfield, John Enright, David Herdrich, Ray Talufono, and Julie Taomia. Matthew Reetz skillfully drew the figures and helped with other aspects of manuscript preparation. For comments on the manuscript, we thank David Burney and Jeremy Kirchman.

\section{Literature Cited}

Amerson, A. B., Jr., W. A. Whistler, and T. D. Schwaner. 1980. Wildlife and wildlife habitat of American Samoa II. Accounts of flora and fauna. U.S. Department of the Interior, Fish and Wildlife Service, Washington, D.C.

. 1982a. Wildlife and wildlife habitat of American Samoa. I. Environment and ecology. U.S. Department of the Interior, Fish and Wildlife Service, Washington, D.C.

- 1982b. Wildlife and wildlife habitat of American Samoa. II. Accounts of flora and fauna. U.S. Department of the Interior, Fish and Wildlife Service, Washington, D.C.

Anderson, A., and G. Clark. 1999. The age of Lapita settlement in Fiji. Archaeol. Oceania 34:31-39.

Austin, C. C. 1999. Lizards took express train to Polynesia. Nature (Lond.) 397:113-114.

Banks, R. C. 1984. Bird specimens from American Samoa. Pac. Sci. 38:150-169.

Bellingham, M., and A. Davis. 1988. Forest bird communities in Western Samoa. Notornis 35:117-128.

Brown, W. C. 1991. Lizards of the genus Emoia (Scincidae) with observations on their evolution and biogeography. Calif. Acad. Sci. Mem. 15:1-94.

Burley, D. V., E. Nelson, and R. Shutler Jr. 1999. A radiocarbon chronology for the Eastern Lapita frontier in Tonga. Archaeol. Oceania 34:59-70.

Elmqvist, T., W. E. Rainey, E. D. Pierson, and P. A. Cox. 1994. Effects of tropical cyclones Ofa and $\mathrm{Val}$ on the structure of a Samoan lowland rain forest. Biotropica 26:384-391.
Engbring, J., and F. L. Ramsey. 1989. A 1986 survey of the forest birds of American Samoa. U.S. Fish and Wildlife Service Administrative Report.

Evans, S. M., F. J. C. Fletcher, P. J. Loader, and F. G. Rooksby. 1992. Habitat exploitation by landbirds in the changing Western Samoan environment. Bird Conserv. Int. 2:123-129.

Fisher, R. N. 1999. Dispersal and evolution of the Pacific Basin gekkonid lizards $G e-$ byra oceanica and Gebyra mutilata. Evolution 51:906-921.

Franklin, J., D. R. Drake, L. A. Bolick, D. S. Smith, and T. J. Motley. 1999. Rain forest composition and patterns of secondary succession in the Vava'u Island Group, Tonga. J. Veg. Sci. 10:51-64.

Freeman, J. D. 1944. The Falemaunga caves. J. Polynesian Sci. 53:86-106.

Freifeld, H. B. 1999. Habitat relationships of forest birds on Tutuila Island, American Samoa. J. Biogeogr. 26:1191-1213.

Freifeld, H. B., D. W. Steadman, and J. K. Sailer. 2001. Landbirds on offshore islands in Samoa. J. Field Ornithol. 72:72-85.

Grant, G. S., S. A. Banack, and P. Trail. 1994. Decline of sheath-tailed bat Emballonura semicaudata (Chiroptera: Emballonuridae) on American Samoa. Micronesica 27:133-137.

Green, R. C., and J. Davidson, eds. 1969. Archaeology in Western Samoa, Vol. I. Bull. Auckl. Inst. Mus. 6. - 1974. Archaeology in Western Samoa, Vol. II. Bull. Auckl. Inst. Mus. 7.

Hoch, H., and M. Asche. 1988. A new troglobitic meenoplid from a lava tube in Western Samoa (Homoptera, Fulgoroidea, Meenoplidae). J. Nat. Hist. 22:1489-1494.

Ineich, I., and G. R. Zug. 1991. Nomenclatural status of Emoia cyanura (Lacertilia, Scincidae) populations in the central $\mathrm{Pa}$ cific. Copeia 1991:1132-1136.

James, H. F., and S. L. Olson. 1991. Descriptions of thirty-two species of birds from the Hawaiian Islands: Part II. Passeriformes. Ornithol. Monogr. 46.

James, H. F., T. W. Stafford Jr., D. W. Steadman, S. L. Olson, P. S. Martin, A. J. 
T. Jull, and P. C. McCoy. 1987. Radiocarbon dates on bones of extinct birds from Hawaii. Proc. Natl. Acad. Sci. U.S.A. 84:2350-2354.

Jennings, J. D., R. N. Holmer, J. C. Janetslei, and H. L. Smith. 1976. Excavations on Upolu, Western Samoa. Pac. Anthropol. Rec. 25:1-113.

Kear, D., and B. L. Wood. 1959. The geology and hydrology of Western Samoa. N. Z. Geol. Surv. Bull. 63.

Keating, P. 1985. Paleomagnetic studies of the Samoan Islands: Results from the islands of Tutuila and Savai'i. Pages 187199 in T. M. Brocher, ed. Geological investigations of the northern Melanesian borderland. Circum-Pacific Council for Energy and Mineral Resources, Earth Science Series. Vol. 3. Houston, Texas.

Kirch, P. V., and T. L. Hunt, eds. 1993. The To'aga Site: Three millennia of Polynesian occupation in the Manu'a Islands, American Samoa. Univ. Calif. Archaeol. Res. Fac. Contrib. 51.

Koopman, K. F., and D. W. Steadman. 1995. Extinction and biogeography of bats on 'Eua, Kingdom of Tonga. Am. Mus. Novit. 3125.

Moritz, C., T. J. Case, D. T. Bolger, and S. Donnellan. 1993. Genetic diversity and the history of Pacific island house geckos (Hemidactylus and Lepidodactylus). Biol. J. Linn. Soc. 48:113-133.

Nagaoka, L. 1993. Faunal assemblages from the To'aga site. Univ. Calif. Archaeol. Res. Fac. Contrib. 51:189-216.

Natland, J. H., and D. L. Turner. 1985. Age progression and petrological development of Samoan shield volcanoes: Evidence from $\mathrm{K}-\mathrm{Ar}$ ages, lava compositions, and mineral studies. Pages 139-171 in T. M. Brocher, ed. Geological investigations of the northern Melanesian borderland. Circum-Pacific Council for Energy and Mineral Resources Earth Science Series. Vol. 3. Houston, Texas.

Olson, S. L., and H. F. James. 1991. Descriptions of thirty-two species of birds from the Hawaiian Islands: Part I. Nonpasseriformes. Ornithol. Monogr. 45.

Pratt, H. D., P. L. Bruner, and D. G. Berrett.
1987. A field guide to the birds of Hawaii and the tropical Pacific. Princeton University Press, Princeton, New Jersey.

Pregill, G. K. 1993. Fossil lizards from the Late Quaternary of 'Eua, Tonga. Pac. Sci. 47:101-114.

Pregill, G. K., and T. H. Worthy. 2003. A new iguanid lizard (Squamata, Iguanidae) from the Late Quaternary of Fiji, Southwest Pacific. Herpetologica 59:57-67.

Schwaner, T. D. 1980. Reproductive biology of lizards on the American Samoa Islands. Occas. Pap. Mus. Nat. Hist., Univ. Kans. $86: 1-53$.

Schwaner, T. D., and W. C. Brown. 1984. Taxonomic status and distribution of the scincid lizards Emoia adspersa Steindachner and $E$. lawesii Günther on islands of the southwestern Pacific. Herpetologica 40:158-164.

Simkin, T., L. Siebert, L. McClelland, D. Bridge, C. Newhall, and J. H. Latter. 1981. Volcanoes of the world. Hutchinson Ross Publishing Co., Stroudsburg, Pennsylvania.

Steadman, D. W. 1986. Holocene vertebrate fossils from Isla Floreana, Galápagos. Smithson. Contrib. Zool. 413:1-103.

- 1990. Archaeological bird bones from Ofu: Extirpations of shearwaters and petrels. Pages 14-15 in P. V. Kirch, T. L. Hunt, L. Nagaoka, and J. Tyler. An ancestral, Polynesian occupation site at To'aga, Ofu Island, America Samoa. Archaeol. Oceania 25:1-15.

- 1993a. Biogeography of Tongan birds before and after human impact. Proc. Natl. Acad. Sci. U.S.A. 90:818-822.

- 1993b. Bird bones from the To'aga site, Ofu, American Samoa: Prehistoric loss of seabirds and megapodes. Univ. Calif. Archaeol. Res. Fac. Contrib. 51: 217-228.

. 1999. Biogeography and extinction of megapodes in Oceania. Zool. Verh. (Leiden) 327:7-21.

- In press. Extinction and biogeography of tropical Pacific birds. University of Chicago Press, Chicago.

Steadman, D. W., and V. B. DeLeon. 1999. First highly stratified prehistoric verte- 
brate sequence from the Galápagos Islands, Ecuador. Pac. Sci. 53:129-143.

Steadman, D. W., and H. B. Freifeld. 1998. Distribution, relative abundance, and habitat relationships of landbirds in the Vava'u Group, Kingdom of Tonga. Condor 100:609-628.

Steadman, D. W., T. H. Worthy, A. J. Anderson, and R. Walter. 2000. New species and records of birds from prehistoric sites on Niue, Southwest Pacific. Wilson Bull. 112:165-186.

Steadman, D. W., G. K. Pregill, and D. V. Burley. 2002. Rapid prehistoric extinction of iguanas and birds in Polynesia. Proc. Natl. Acad. Sci. U.S.A. 99:3673-3677.

Thomson, J. A. 1921. The geology of Western Samoa. N. Z. J. Sci. Technol. 4:49-66.
Whistler, W. A. 1980. The vegetation of Eastern Samoa. Allertonia 2:45-190.

-. - 1983. Vegetation and flora of the Aleipata Islands, Western Samoa. Pac. Sci. 37:227-250.

-1992. Vegetation of Samoa and Tonga. Pac. Sci. 46:159-178.

Zug, G. R. 1991. The lizards of Fiji: Natural history and systematics. Bishop Mus. Bull. Zool. 2:1-136.

- 1998. Australian populations of the Nactus pelagicus complex. Mem. Queensl. Mus. 42:613-626.

Zug, G. R., and B. R. Moon. 1995. Systematics of the Pacific slender-toed geckos, Nactus pelagicus complex: Oceania, Vanuatu, and Solomon Islands populations. Herpetologica 51:77-90. 